\title{
PENGEMBANGAN MODEL PEMBELAJARAN TERPADU BERBASIS BUDAYA UNTUK MENINGKATKAN APRESIASI SISWA TERHADAP BUDAYA LOKAL
}

\author{
Alexon* dan Nana Syaodih Sukmadinata** \\ FKIP Universitas Bengkulu* dan Pascasarjana Universitas Pendidikan

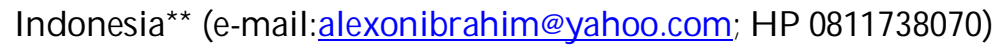

\begin{abstract}
Developing a Culture-Based Integrated Learning Model to Improve Students' Appreciation of Local Culture. This study aims to develop a social study learning model for elementary school students that can help them master subject matters as an effort to improve their appreciation of local culture, using an R \& D approach consisting of three steps: preliminary study, model development and model validation. The subjects were teachers and students of elementary schools in Bengkulu Province, Sumatra. The results show that the Culture-Based Integrated Learning Model (CBILM) is an appropriate learning model to help students master subject matters as an effort to improve their appreciation of local culture. CBILM is more capable of significantly improving students' appreciation of local culture and their mastery of subject matters than the currently existing learning model.
\end{abstract}

Keywords: learning model, social studies for elementary schools, culture appreciation

\section{PENDAHULUAN}

Dua hal penting yang melatarbelakangi penelitian ini. Pertama, tantangan yang dihadapi lembaga pendidikan dasar di era globalisasi. Kedua, sistem pendidikan di sekolah yang cenderung parsial telah menjadikan manusia-manusia Indonesia kurang mengapresiasi budayanya.

Pertama, globalisasi mengakibatkan pencapaian tujuan pendidikan tingkat satuan pendidikan dasar untuk meletakkan dasar keterampilan hidup mandiri semakin kompleks. Tilaar (2006) mengemukakan tiga kekuatan besar yang akan mempengaruhi kehidupan individu Indonesia di era globalisasi, yakni masyarakat madani (civil society), negara-bangsa (nation-state), dan globalisasi. Oleh karena itu, agar tidak terombang-ambing dalam tiga kekuatan besar tersebut, manusia Indonesia harus memiliki dan bertindak sesuai dengan nilai-nilai Pancasila. Nilai-nilai Pancasila merupakan kristalisasi dari nilainilai budaya lokal yang merupakan nilai-nilai yang pertama-tama dikenal oleh seorang manusia Indonesia. Hal ini menekankan pentingnya sejak dini dan melembaga untuk memelihara dan mengembangkan budaya lokal sebagai bagian integral dari pendidikan nasional, 
khususnya pembelajaran di SD, agar siswa tidak tercabut dari akar budayanya.

Kedua, secara konsepsional, mata pelajaran IPS dekat dengan lingkungan. Oleh karena itu, pembelajaran IPS SD seharusnya memanfaatkan secara optimal potensi lingkungan agar lebih bermakna. Kenyataannya di Indonesia, hal ini belum dilakukan guru. Pembelajaran IPS SD cenderung tidak kontekstual. Potensi lingkungan setempat, khususnya budaya lokal, tidak dimanfaatkan guru secara optimal dalam proses pembelajaran. Pembelajaran tetap mengutamakan pengembangan aspek intelektual dengan buku teks pegangan guru menjadi sumber belajar utama. Beberapa kesimpulan hasil penelitian menunjukkan hal ini, antara lain Pargito di Lampung (2000:112), Hadi di Jawa Timur (1997:101), Samion di Kalimantan Barat (2002:25), serta Sasongko (2004:3) maupun Sapri (2000:16) di Bengkulu. Hal ini mengakibatkan siswa kurang mengapresiasi budayanya.

Apresiasi sendiri merupakan istilah yang berasal dari appreciation dan bahasa Latinnya disebut apreciatic yang berarti mengindahkan atau menghargai (Suryatin, 1997:50). Philip dan Phil (Wangsih, 2002:26) mengartikan apresiasi sebagai pemahaman dan penghargaan atas suatu hasil seni atau budaya serta menimbang suatu nilai, merasakan bahwa benda itu baik dan mengerti mengapa baik. Apresiasi merupakan pemahaman, penginterpretasian dan penilaian/penghargaan atas suatu hasil seni atau budaya. Hal ini sesuai dengan pendapat Atmazaki(1992:144-146) yang mengemukakan tiga indikator kemam- puan mengapresiasi budaya, yakni pemahaman, penginterpretasian, dan penilaian/penghargaan. Apresiasi dapat terjadi bila seseorang mengalami pengalaman, baik langsung maupun tidak langsung, di dalam karya seni atau budaya tersebut (Rusyana, 1984:322). Apresiasi dapat diketahui dengan pengamatan, bertanya langsung maupun tidak langsung, dan tes.

Pembelajaran untuk meningkatkan apresiasi siswa terhadap budaya menekankan pembelajaran bermakna. Fink (2003:6-7) mengenai pembelajaran bermakna mengemukakan bahwa apa yang dipelajari mempunyai potensi tinggi untuk dimanfaatkan dalam kehidupannya, baik kehidupan pribadi maupun partisipasi dalam kehidupan bermasyarakat. Sementara Sayakti (2003:132) menekankan pentingnya pembelajaran IPS SD menggunakan konsep lingkungan, khususnya budaya lokal, sebagai sumber belajar agar lebih bermakna.

Pembelajaran bermakna merupakan pembelajaran yang dikemas sesuai dengan karakteristik siswa. Karakteristik siswa SD yang masih berpikir konkrit dan realistik memerlukan pengemasan pembelajaran yang konkrit dan terpadu. Hal ini relevan dengan tujuan mata pelajaran IPS yang menyeluruh dan diorientasikan pada penguasaan pengetahuan, keterampilan, nilai dan sikap agar siswa mampu berpartisipasi dalam berbagai lingkungan (Schuncke, 1988: 232; Barr, Bart dan Shemis, 1978:17-19). Tujuan ini menekankan pentingnya pengemasan pembelajaran terpadu yang memberikan kesempatan kepada siswa untuk belajar berbuat melalui peme- 
cahan masalah yang muncul dalam kehidupan sehari-hari.

Pembelajaran IPS SD terpadu yang holistik-kontekstual, secara konsepsional diharapkan dapat meningkatkan apresiasi siswa terhadap budaya lokal apabila fokus pada tema budaya yang dikembangkan dengan mengintegrasikan budaya dalam prosesnya. Pengintegrasian budaya dalam proses pembelajaran memerlukan pendekatan pembelajaran berbasis budaya. Pannen (dalam Suprayekti, 2004:4.9) mengemukakan bahwa pembelajaran berbasis budaya merupakan strategi penciptaan lingkungan belajar dan perancangan pengalaman belajar yang mengintegrasikan budaya sebagai bagian dari proses pembelajaran. Pembelajaran ini berlandaskan pandangan konstruktivisme yang mengutamakan penciptaan makna di mana siswa mengkonstruksi pengetahuannya berdasarkan pengalaman awal budaya yang telah dimilikinya.

Pembelajaran IPS SD terpadu berbasis budaya yang holistik-konstruktivistik, berangkat dari tema budaya dan dikembangkan berdasarkan pengalaman awal budaya siswa. Pendekatan pembelajaran seperti ini diharapkan dapat memfasilitasi siswa menguasai materi pelajaran sebagai upaya meningkatkan apresiasinya terhadap budaya lokal.

Pandangan-pandangan di atas menegaskan bahwa ada permasalahan dalam pendidikan IPS di SD yang memerlukan solusi. Hal ini, membutuhkan upaya untukmemperbaiki kualitas pembelajaran IPS SD agar lebih bermakna sebagai upaya meningkatkan apresiasi siswa terhadap budaya lokal. Sukmadinata (2006:7), mengenai upaya perbaik- an kualitas pembelajaran ini mengemukakan tiga komponen yang berpengaruh pada proses pembelajaran, yakni raw input (karakteristik siswa), instrumental input (kebijakan, kurikulum, personalia, sarana-prasarana), dan enviromental input (lingkungan). Dunkin dan Biddle (1974:38) mengemukakan variabel yang mempengaruhi pembelajaran di kelas adalah presage variable, context variable, process variable, dan product variable. Kedua pandangan ini menekankan pentingnya peranan guru dalam memperbaiki kualitas pembelajaran IPS. Oleh karenanya, upaya perbaikan dapat dimulai dari proses pembelajaran yang dilaksanakan guru.

Penelitian ini diorientasikan menghasilkan model pembelajaran IPS SD yang dapat memfasilitasi siswa menguasai materi pelajaran sebagai upaya meningkatkan apresiasinya terhadap budaya lokal. Masalah pokoknya adalah model IPS SD bagaimanakah yang cocok untuk memfasilitasi siswa menguasai materi pelajaran sebagai upaya meningkatkan apresiasinya terhadap budaya lokal.

Secara konsepsional, kurikulum IPS SD yang berkaitan dengan budaya lokal diberikan pada kelas IV. Oleh karena itu, penelitian ini fokus pada kurikulum IPS SD kelas IV. Budaya lokal pada penelitian ini mengacu pada budaya Tabot di Bengkulu, lokasi dimana penelitian dilaksanakan. Masyarakat Bengkulu sendiri merupakan komunitas budaya Tabot (Norman, 1997:8-10).

Ada dua tujuan utama penelitian, yakni (1) menemukan model pembelajaran IPS SD yang dapat memfasilitasi siswa menguasai materi pelajaran 
sebagai upaya meningkatkan apresiasinya terhadap budaya lokal; dan (2) mengetahui efektifitas keberhasilan implementasi model pembelajaran IPS SD hasil pengembangan bila dibandingkan dengan model pembelajaran konvensional.

\section{METODE}

Penelitian ini menggunakan pendekatan research and development (penelitian dan pengembangan) sebagaimana dikemukakan Borg dan Gall (1989:784785). Implementasi 10 langkah peneli- tian yang dikemukakan Borg dan Gall, dalam penelitian ini dimodifikasi dalam tiga tahapan proses penelitian dan pengembangan, yakni (1) studi pendahuluan yang meliputi studi pustaka, survei lapangan dan analisis potensi budaya lokal; (2) pengembangan model yang meliputi kegiatan penyusunan draf awal model, uji coba terbatas dan uji coba lebih luas; dan (3) validasi model. Bagan di bawah ini menyajikan prosedur penelitian dan pengembangan yang dilaksanakan.

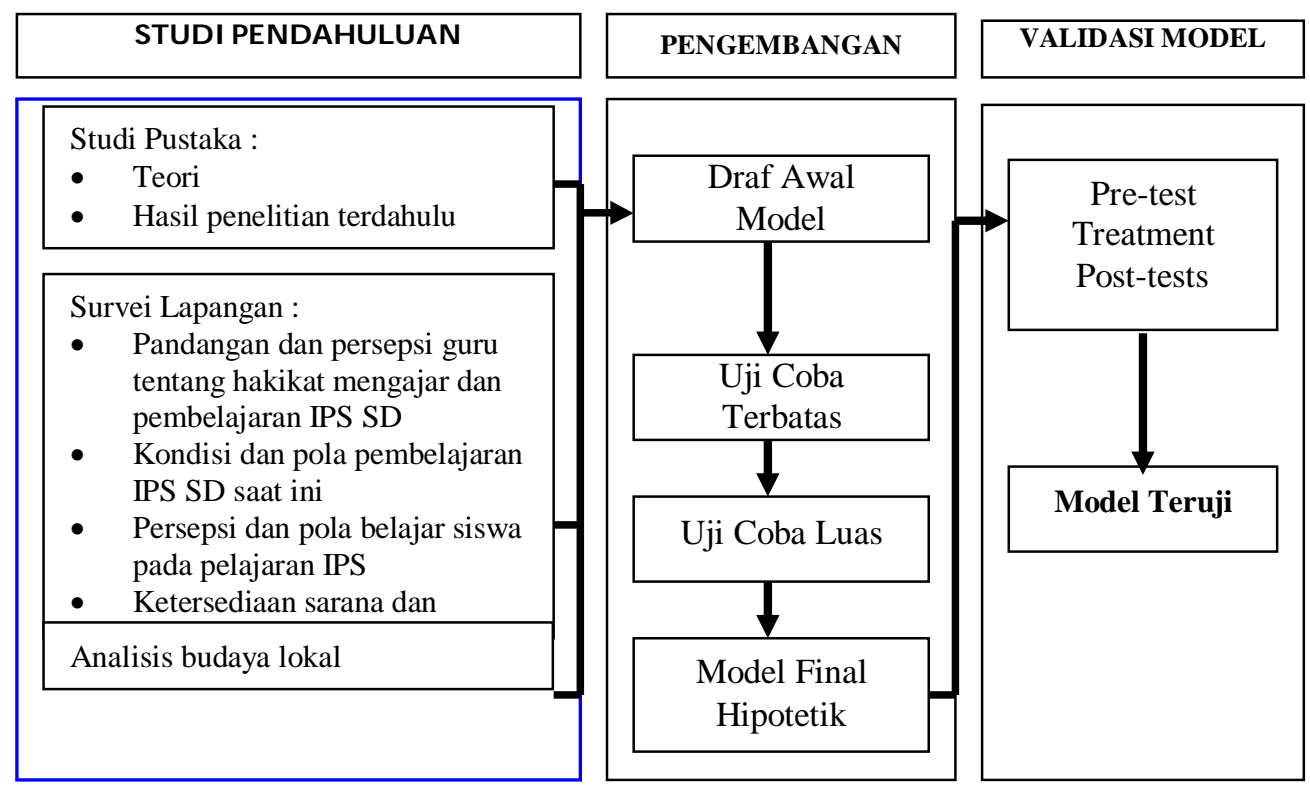

Bagan 1. Prosedur Penelitian dan Pengembangan

Penelitian ini dilaksanakan pada SD di Kota Bengkulu. Berdasarkan pendekatan dan prosedur penelitian, lokasi penelitian ditetapkan 4 kelompok, yakni (1) lokasi prasurvei; (2) lokasi uji coba terbhatas; (3) lokasi uji coba lebih luas; dan (4) lokasi uji validasi model.
Lokasi prasurvei dilaksanakan di 8 kecamatan yang ada di Kota Bengkulu (sampling daerah 100\%). Setiap kecamatan, secara random sampling sederhana, ditetapkan 2 SD yang dijadikan lokasi prasurvei. Oleh karena itu, ada 16 SD yang menjadi lokasi penelitian prasurvei. Subjek penelitian adalah kepala 
sekolah, guru IPS dan siswa kelas IV di setiap sekolah bersangkutan.

Lokasi uji coba terbatas ditetapkan 1 SD. Penetapan 1 SD ini dilakukan dengan teknik purposive sampling. Teknik ini digunakan apabila peneliti memiliki pertimbangan tertentu dalam menetapkan sampel sesuai dengan tujuan penelitian (Sudjana dan Ibrahim, 1989). Pertimbangan yang digunakan adalah (1) kesediaan dan motivasi yang tinggi dari pihak sekolah, khususnya kepala sekolah dan guru IPS untuk bekerjasama dengan peneliti dalam pengembangan model pembelajaran; (2) ketersediaan fasilitas sekolah yang memenuhi kebutuhan minimal untuk pengembangan model pembelajaran. Subjek penelitian adalah guru IPS dan siswa kelas IV SD bersangkutan.

Berdasarkan pertimbangan yang sama seperti di atas, lokasi SD untuk uji coba lebih luas ditetapkan tiga SD yang masing-masing berkategori baik, sedang dan kurang. Penentuan kategori sekolah didasarkan pada rekomendasi Dinas Pendidikan setempat, nilai ujian nasional, serta pengamatan yang dilakukan peneliti selama ini. Subjek penelitian adalah guru IPS dan siswa kelas IV SD bersangkutan.

Uji validasi dilaksanakan dengan menggunakan eksperimen. Desain yang digunakan adalah Matching Pretest-posttest Control Group Design (Sukmadinata, 2007:207). Subjek penelitian di bagi dalam dua kelompok, eksperimen dan kontrol. Setiap kelompok terdiri atas sekolah baik, sedang dan kurang yang ditetapkan sesuai dengan pertimbangan sebagaimana disebutkan di atas. SD yang menjadi subjek penelitian pada uji validasi disajikan pada tabel di bawah ini.

Tabel 1.Subjek Penelitian untuk Uji Validasi Model Pembelajaran

\begin{tabular}{lcc}
\hline Kelompok & Eksperimen & Kontrol \\
\cline { 1 - 1 } $\begin{array}{c}\text { Kategori } \\
\text { Sekolah }\end{array}$ & & \\
\hline Baik & & \\
Sedang & SDN 8 & SDN 5 \\
Kurang & SDN 47 & SDN 2 \\
\hline
\end{tabular}

Teknik pengumpulan data yang digunakan adalah pengamatan (observasi), wawancara, kuesioner, analisis dokumen, serta instrumen apresiasi dan tes hasil belajar. Ada dua jenis data yang dihasilkan pada penelitian ini, yakni data kualitatif dan data kuantitatif. Data kualitatif dihasilkan pada saat studi pendahuluan dan pengembangan model. Sementara data kuantitatif dihasilkan pada tahap pengembangan dan validasi model. Analisis data kualitatif dilakukan melalui penafsiran secara langsung, sedangkan data kuantitatif dianalisis dengan prosedur statistik uji-t yang pengolahannya dibantu komputer program SPSS 15.

\section{HASIL PENELITIAN}

Hasil prasurvei menunjukkan sebagian besar guru $(71,88 \%)$ berpendapat bahwa mata pelajaran IPS merupakan mata pelajaran sosial yang hanya dapat dikuasai siswa dengan menghafal. Hal ini berimplikasi pada pendapat guru $(78,13 \%)$ terhadap tujuan pembelajaran IPS SD, yaitu menguasai materi pelajaran sebanyak-banyaknya. Guru memahami bahwa secara konsepsional materi pelajaran IPS SD, khususnya 
kelas IV, berkaitan dengan budaya lokal, namun sebagian besar mereka $(75,00 \%)$ mengaku tidak harus mengintegrasikannya dalam proses pembelajaran.Selanjutnya, gurutersebut $(71,88 \%)$ mengemukakan bahwa mereka belum pernah mengintegrasikan budaya lokal dalam pelajaran IPS. Oleh karena itu, mereka $(75,00 \%)$ mengakui bahwa apresiasi siswa terhadap budaya lokal rendah.

Rencana Pelaksanaan Pembelajaran (RPP) menurut sebagian besar guru (71,88\%) hanya untuk keperluan administratif dan sebagai pelengkap saja karena proses pembelajaran lebih banyak berorientasi pada buku teks pegangan guru. RPP tidak dibuat sendiri oleh guru, tapi disalin dari sekolah lain, khususnya sekolah di Pulau Jawa yang dianggap baik. Oleh karena itu, sangat wajar apabila guru dalam merencanakan pembelajaran tidak mengakomodasi sama sekali budaya lokal seperti Tabot. Semua guru mengakui metode ceramah merupakan metode yang mendominasi proses pembelajaran IPS SD di kelas. Metode lain yang kadang-kadang digunakan guru adalah tanya-jawab, pemberian tugas dan kerja kelompok. Evaluasi belajar lebih diutamakan untuk mengukur penguasaan materi pelajaran oleh siswa.

Sebagian besar $(57,14 \%)$ siswa SD berpendapat bahwa pelajaran IPS membosankan dan sulit karena banyak bahan yang harus dihafal. Tujuan belajar IPS menurut mereka $(69,84 \%)$ adalah mendapatkan nilai baik dan naik kelas. Cara mengajar guru menurut siswa $(61,90 \%)$ lebih banyak menjelaskan ba- han pelajaran yang ada di buku pelajaran. Cara belajar siswa kelas, menurut sebagian besar siswa $(67,90 \%)$, adalah mendengarkan guru menjelaskan dan mencatat. Sebagian besar siswa $(53,17 \%)$ mengaku pernah menonton perayaan budaya Tabot, dan merasa senang menontonnya karena menarik dan ramai (93,65\%). Hanya sebagian kecil $(20,24 \%)$ siswa yang mengaku mengenal Tabot karena cerita guru di kelas. Tujuan perayaan budaya Tabot menurut sebagian besar siswa $(54,36 \%)$ adalah hiburan masyarakat. Hampir seluruh siswa $(92,06 \%)$ menyatakan tidak tahu bagaimana asal-usul sejarah budaya Tabot.

Semua sekolah mempunyai cukup lengkap media yang dapat mendukung pengintegrasiaan budaya Tabot dalam pembelajaran IPS SD, khususnya perangkat musik tradisional Dol, gambargambar perayaan Tabot serta bendabenda simbolik yang berkaitan dengan upacara tradisional Tabot. Media perangkat budaya selama ini hanya dimanfaatkan untukmendukung pengembangan program ekstra-kurikuler. Sementara kebijakan kepala sekolah dan iklim sosial-psikologis sekolah serta pandangan tokoh masyarakat Bengkulu kondusif bagi pengembangan model pembelajaran IPS SD untuk meningkatkan apresiasi siswa terhadap budaya lokal.

Berdasarkan kajian teoretis, hasil prasurvei, dan hasil diskusi dengan guru-guru yang menjadi subjek penelitian, maka dikembangkanlah desain awal (draf) model perencanaan pembelajaran terpadu berbasis budaya sebagaimana disajikan di bawah ini. 
1. Tema :

Budaya lokal.

2. Tujuan Pembelajaran :

Memfasilitasi siswa menguasai materi pelajaran IPS sesuai dengan kompetensi dasar dan indikator yang hendak dicapai sebagai upaya meningkatkan apresiasinya terhadap budaya lokal.

3. Materi Pokok :

Tema budaya lokal yang dihubungkan dengan topik pelajaran IPS sesuai dengan kompetensi dasar dan indikator yang hendak dicapai siswa sebagai upaya meningkatkan apresiasinya terhadap budaya lokal.

4. Kegiatan Pembelajaran :

Kegiatan pembelajaran menggunakan MPTBB dengan tiga tahap pokok, yakni :

a. Pendahuluan, yang merupakan tahapan apersepsi guna menggali pengetahuan awal siswa tentang pelajaran IPS yang lalu yang dikaitkan dengan tema budaya lokal, kemudian diarahkan ke topik pelajaran IPS yang baru.

b. Inti, yang merupakan tahapan yang menekankan tugas bermakna, interaksi aktif, dan aplikasi kontekstual melalui langkah eksplorasi, diskusi dan pendalaman konsep, serta pengembangan dan aplikasi.

c. Penutup, yang merupakan tahapan penyimpulan.

5. Sumber, Alat dan Media :

Sumber, alat dan media pembelajaran yang mendukung pencapaian kompetensi dasar dan indikator sebagai upaya meningkatkan apresiasi siswa terhadap budaya lokal.

6. Penilaian : Penilaian proses dan hasil.

Bagan 2. Desain Awal Model Perencanaan Pembelajaran Terpadu Berbasis Budaya

Selanjutnya dilakukan uji coba terbatas terhadap desain awal (draf) Model Pembelajaran Terpadu Berbasis Budaya (MPTBB) yang dirancang dapat memfasilitasi siswa menguasai materi pelajaran IPS sebagai upaya meningkatkan apresiasinya terhadap budaya lokal. Uji-coba bertujuan untuk mengembangkan draf model awal yang telah dirancang.

Uji coba terbatas dilaksanakan dalam lima putaran. Penentuan banyaknya putaran berdasarkan keberhasilan guru mengimplementasikan MPTBB sesuai dengan tujuan yang ditetapkan.
Setelah uji-coba terbatas 5 putaran, model pembelajaran yang ditemukakan dianggap sudah memadai. MPTBB sebagai hasil pengembangan pada uji-coba terbatas mengalami perubahan dibandingkan draf awalnya, khususnya pada kegiatan pembelajaran. Perubahan tersebut antara lain adalah setiap tahap pembelajaran mengandung langkah yang lebih spesifik.

Tahap pendahuluan mengandung langkah simulasi budaya, apersepsi berbasis budaya, dan sosialisasi. Pada tahap inti, terjadi pengembangan, baik pada fase eksplorasi, diskusi dan pen- 
dalaman konsep, serta pengembangan dan aplikasi. Fase eksplorasi menjadi lebih spesifik dan rinci, yakni (1) siswa menyimak dan merespon penjelasan guru mengenai tema budaya yang dikaitkan topik pelajaran IPS, serta diakhiri dengan pemberian tugas diskusi kelompok bermakna yang relevan dalam pelajaran IPS; (2) menggali dan membaca buku sumber, termasuk buku sumber supplement khusus MPTBB; dan (3) diskusi kelompok yang difasilitasi, dibimbing dan dipantau guru. Fase lainnya pada pembelajaran tahap inti MPTBB yang sudah dikembangkan adalah diskusi dan pendalaman konsep, terdiri atas dua langkah, yaitu (1) siswa mempresentasikan hasil diskusi kelompoknya dan memberikan pendapat terhadap hasil kelompok lain; serta (2) menyimak dan merespon umpan-balik dan penjelasan yang diberikan guru. Sedangkan fase pengembangan dan aplikasi terdiri atas satu langkah, yakni siswa mengerjakan tugas yang bersifat pengembangan dan aplikasi. Pembelajaran dengan menggunakan MPTBB yang telah dikembangkan pada tahap uji coba terbatas, diakhiri dengan tahap penutup yang terdiri atas dua langkah, yakni penyimpulan bersama hasil pembelajaran yang baru di lalui, serta pemberian tindak lanjut bagi siswa sebagai bagian persiapan pembelajaran berikutnya.

Setelah uji coba terbatas, selanjutnya dilakukan uji coba lebih luas untuk menemukan MPTBB sebagai suatu model pembelajaran yang standar dan dapat diimplementasikan pada setiap sekolah dengan kategori berbeda, yakni sekolah kategori baik, sedang dan ku- rang. Pada uji coba luas, di samping dilakukan analisis proses pembelajaran untuk menemukan MPTBB, juga dilakukan analisis hasil pembelajaran. Sebelum uji coba luas dilaksanakan, diadakan lokakarya untuk para guru yang terlibat. Lokakarya ini bertujuan menyamakan persepsi para guru, baik secara konsepsional maupun operasional mengenai MPTBB. Uji coba luas dilaksanakan dalam tiga putaran. Hal ini berdasarkan keyakinan bahwa MPTBB, baik berdasarkan observasi maupun perhitungan kuantitatif-statistik, telah dapat dikembangkan dan dianggap memadai sesuai dengan tujuan yang ditetapkan.

Hasil uji coba luas, tidak ada perbaikan MPTBB yang prinsip. Tahap-tahap pengembangan model sebagaimana yang dihasilkan pada uji coba terbatas sudah memadai sebagai model pembelajaran yang bertujuan memfasilitasi siswa menguasai materi pelajaran IPS sebagai upaya meningkatkan apresiasinya terhadap budaya lokal.

Tahap pendahuluan merupakan tahap pengkondisian. Hal ini karena tujuannya adalah menciptakan kondisi awal pembelajaran bernuansa budaya yang kondusif untuk mendorong partisipasi aktif siswa dalam proses penciptaan makna baru. Tahap ini menekankan pembentukan kemampuan siswa dalam menciptakan hubungan-hubungan bermakna antara budaya dan konsep IPS yang dikembangkan berdasarkan pengalaman awal siswa sebagai anggota suatu komunitas budaya. Tahap penutup merupakan tahap konsolidasi. Pada tahap ini, guru bersama-sama siswa mengkonsolidasikan hasil belajar 
yang telah ditempuh melalui kegiatan penyimpulan bersama hasil belajar dan tindak lanjut.

Perbaikan model pada uji coba lebih luas ini lebih pada aspek implementasi oleh guru pada setiap tahapan yang sifatnya menambah kejelasan dan ketajaman model yang dikembangkan. Perbaikan lebih pada aspek desain evaluasi. Desain evaluasi MPTBB dilakukan dalam dua bentuk, yakni evaluasi proses dan evaluasi hasil. Evaluasi proses dilakukan terintegrasi dengan proses pembelajaran dalam bentuk observasi apresiasi siswa terhadap budaya lokal Tabot dan observasi aktivitas siswa dalam diskusi kelompok maupun kelas. Sementara evaluasi hasil dilakukan melalui LKS diskusi kelompok, LKS tugas individual pengembangan dan aplikasi, serta tes.

Secara keseluruhan, MPTBB untuk meningkatkan apresiasi siswa terhadap budaya lokal yang siap divalidasi adalah sebagai berikut.

\section{DESAIN}

1. Tema :

Budaya lokal.

2. Tujuan Pembelajaran :

Memfasilitasi siswa menguasai materi pelajaran IPS sesuai dengan kompetensi dasar dan indikator yang hendak dicapai sebagai upaya meningkatkan apresiasinya terhadap budaya lokal.

3. Materi Pokok:

Tema budaya lokal yang dihubungkan dengan topik pelajaran IPS sesuai dengan kompetensi dasar dan indikator yang hendak dicapai siswa sebagai upaya meningkatkan apresiasinya terhadap budaya lokal.

4. Kegiatan Pembelajaran :

Kegiatan pembelajaran menggunakan Pembelajaran Terpadu Berbasis Budaya dengan tiga tahap pokok, yakni :

d. Pendahuluan (pengkondisian) yang terdiri atas langkah simulasi budaya, apersepsi yang berangkat dari tema budaya, dan sosialisasi.

e. Inti (penciptaan makna) yang terdiri atas tahapan yang menekankan tugas bermakna, interaksi aktif, dan aplikasi kontekstual melalui langkah eksplorasi berbasis budaya yang diakhiri tugas bermakna, interaksi dengan sumber, diskusi dan pendalaman konsep, serta pengembangan dan aplikasi.

f. Penutup (konsolidasi) yang terdiri atas langkah penyimpulan bersama dan tindak lanjut.

5. Sumber, Alat dan Media :

Buku sumber pelajaran IPS, buku sumber supplement MPTBB, peralatan musik dan simbol-simbol budaya lokal, gambar-gambar budaya-sejarah-geografi-ekonomi dan sosial setempat yang relevan, serta LKS.

6. Penilaian

Penilaian proses dan hasil. 


\section{IMPLEMENTASI}

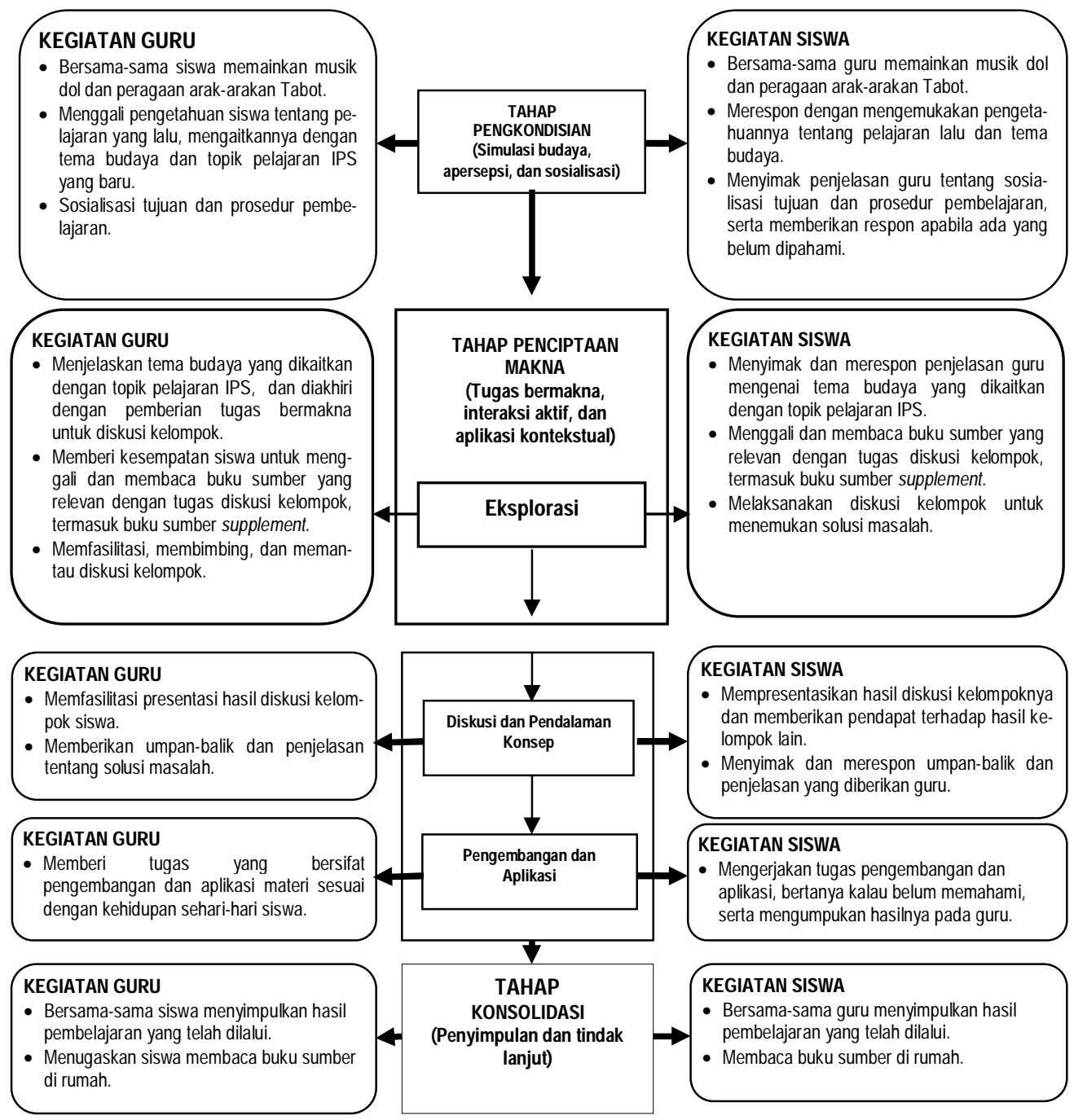

\section{PENILAIAN}

Penilaian proses dan penilaian hasil. Penilaian proses berupa observasi apresiasi siswa terhadap budaya lokal dengan menggunakan rubrik dan format observasi apresiasi; serta observasi aktivitas siswa dalam diskusi dengan menggunakan rubrik dan format observasi aktivitas siswa. Penilaian hasil dilakukan melalui LKS diskusi kelompok, LKS tugas individual pengembangan dan aplikasi, dan tes hasil belajar.

\section{Bagan 3. Model Pembelajaran Terpadu Berbasis Budaya (MPTBB) yang Siap Divalidasi}


Hasil uji validasi membuktikan bahwa penggunaan MPTBB dalam mata pelajaran IPS SD, bukan hanya memiliki pengaruh positif terhadap peningkatan apresiasi siswa terhadap budaya lokal, tetapi juga berpengaruh positif terhadap peningkatan penguasaan siswa terhadap materi IPS. Tabel berikut menyajikan hal tersebut.

Tabel 2. Rata-rata Gain pada Uji Validasi

\begin{tabular}{|c|c|c|c|c|c|c|c|}
\hline \multicolumn{2}{|r|}{$\begin{array}{c}\text { Kategori Sekolah/ } \\
\text { Aspek }\end{array}$} & n & \multicolumn{2}{|c|}{ Rerata Gain } & \multicolumn{3}{|c|}{ Hasil Pengujian } \\
\hline \multicolumn{2}{|c|}{ Sekolah Kategori Baik : } & 64 & & & & & \\
\hline $\begin{array}{l}\text { budaya } \\
\text { lokal }\end{array}$ & $\begin{array}{l}\text { Indikator penginterpretasian dan penilai- } \\
\text { an/penghargaan terhadap budaya lokal }\end{array}$ & & 9,26 & 3,03 & 13,73 & 2,00 & Signifikan \\
\hline \multicolumn{2}{|c|}{ Hasil Belajar } & & 5,94 & 3,23 & 9,68 & 2,00 & Signifikan \\
\hline \multicolumn{2}{|c|}{ Sekolah Kategori Sedang : } & 59 & & & & & \\
\hline \multicolumn{2}{|c|}{ Hasil Belajar } & & 5,58 & 2,82 & 12,69 & 2,02 & Signifikan \\
\hline \multicolumn{2}{|c|}{ Sekolah Kategori Kurang : } & 81 & & & & & \\
\hline $\begin{array}{l}\text { Apresiasi } \\
\text { terhadap }\end{array}$ & $\begin{array}{l}\text { Indikator pemahaman terhadap budaya lo- } \\
\text { kal }\end{array}$ & & 3,10 & 0,95 & 8,95 & 2,00 & Signifikan \\
\hline $\begin{array}{l}\text { budaya } \\
\text { lokal }\end{array}$ & $\begin{array}{l}\text { Indikator penginterpretasian dan penilai- } \\
\text { an/penghargaan terhadap budaya lokal }\end{array}$ & & 7,33 & 2,56 & 13,72 & 2,00 & Signifikan \\
\hline \multicolumn{2}{|c|}{ Hasil Belajar } & & 5,08 & 2,46 & 13,84 & 2,00 & Signifikan \\
\hline
\end{tabular}

Keterangan: Eks. : Kelompok eksperimen

Ktr. : Kelompok kontrol

Pada uji validasi, walaupun pada tes awal terbukti antara kelompok eksperimen dan kelompok kontrol tidak terdapat perbedaan yang signifikan, namun pada tes akhir kelompok eksperimen memperoleh hasil yang lebih tinggi. Hal ini terjadi baik pada sekolah dengan kategori baik, sedang maupun kurang. Gain pada kelompok eksperimen pada sekolah ketegori baik, sedang dan kurang, baik untuk aspek apresiasi (pemahaman serta peninterpretasian dan penilaian/penghargaan), maupun hasil belajar, secara signifikan lebih baik bila dibandingkan dengan kelompok kontrol.

\section{PEMBAHASAN}

Secara substansial, konsep MPTBB dalam pembelajaran IPS dikembangkan berdasarkan prinsip-prinsip pembelajaran terpadu yang holistik dan pembelajaran berbasis budaya yang konstruktivistik. Pendekatan holistik dalam pembelajaran didasari oleh teori Gestalt. Gestalt berasal dari bahasa Jerman yang berarti whole configuration. Pendekatan ini menekankan bahwa pengembangan 
pemahaman baru merupakan suatu bentuk pengembangan individu yang utuh, pola, kesatuan dan keseluruhan yang melibatkan semua aspek dalam kehidupan anak. Sukmadinata (2005: 55), berkenaan dengan konsep Gestalt, mengemukakan bahwa "....belajar merupakan proses pengembangan insight atau pemahaman baru........pemahaman terjadi apabila individu menemukan cara baru dalam menggunakan unsurunsur yang ada dalam lingkungan..".

Pandangan mengenai pendekatan holistik di atas menunjukkan bahwa pendekatan holistik mengutamakan pembelajaran yang utuh, keseluruhan dan konkrit. Pengemasan pembelajaran tidak terpisah-pisah dan selalu melihat suatu objek dalam keutuhan dan keseluruhasnnya sehingga memungkinkan siswa belajar bermakna, otentik dan aktif. Aplikasinya, teori Gestalt menekankan pemerolehan insight dimana siswa memiliki kemampuan mengenal keterkaitan unsur-unsur dalam suatu objek atau peristiwa.

Aplikasinya, pendekatan holistik diimplementasikan melalui model pembelajatan terpadu. Menurut Fogarty (1991:xiv), model pembelajaran terpadu sebagai wujud pendekatan integratif bersifat kontinum yang berawal dari bentuk kurikulum tradisional dimana seluruh mata pelajaran merupakan bidang studi yang diajarkan terpisah-pisah sampai model yang berorientasi pada mata pelajaran yang sangat terpadu. MPTBB dalam hal ini, sesuai dengan karaktersitik pelajaran IPS yang mengintegrasikan berbagai disiplin, berorientasi pada webbed model atau model jaring laba-laba yang lazim juga disebut pendekatan tematik. Model ini sudah familiar bagi guru-guru SD di Indonesia. Implementasinya berangkat dari sebuah tema yang dibangun sendiri oleh guru atau bersama-sama siswa berdasarkan minat, kebutuhan, serta lingkungan sekitar siswa.

Di samping hal di atas, MPTBB juga dikembangkan berdasarkan prinsipprinsip pembelajaran berbasis budaya yang konstruktivistik. Pendekatan konstruktivistik dikembangkan Vygotsky (Social and Emancipatory Construdtivism). Pendekatan ini menekankan bahwa "siswa mengkonstruksi pengetahuan atau menciptakan makna sebagai hasil dari pemikiran dan berinteraksi dalam suatu konteks sosial" (Suprayekti, 2004: 4-14). Proses belajar merupakan bagian integral dari aktivitas dan interaksi seseorang, di mana dalam proses ini aktivitas dan interaksi berlangsung secara simultan dan dialogis. Pengetahuan yang diperoleh seseorang tidak lepas dari aktivitas di mana pengetahuan itu dikonstruksi serta dari komunitas mana budaya tersebut diaplikasikan.

Pembahasan di atas menunjukkan bahwa MPTBB merupakan sebuah model pembelajaran hasil pengembangan yang berbeda dengan model pembelajaran lainnya. Tujuan dari MPTBB adalah meningkatkan apresiasi siswa terhadap budaya lokal sebagai upaya meningkatkan penguasaan materi IPS. Tujuan ini jelas berbeda dengan tujuan pembelajaran IPS selama ini yang lebih mengutamakan penguasaan materi IPS sebanyak-banyaknya. Tujuan konvensional seperti ini tidak mengakomodasi bentuk pengetahuan dan kekayaan tradisional dalam komunitas budayanya. 
Oleh karena itu, MPTBB dikembangkan sesuai dengan kebutuhan dan permasalahan faktual di lapangan dengan menekankan tujuan yang bukan hanya meningkatkan penguasaan materi IPS, tapi lebih dari itu sebagai suatu model pembelajaran yang mampu meningkatkan apresiasi siswa terhadap budaya lokalnya. MPTBB memandang bahwa kedua sisi tujuan tersebut, yakni meningkatkan apresiasi terhadap budaya lokal dan penguasaan materi IPS sebagai dua sisi yang sama pentingnya.

\section{KESIMPULAN}

Pertama, Model Pembelajaran Terpadu Berbasis Budaya (MPTBB) yang dikembangkan untuk meningkatkan apresiasi siswa terhadap budaya lokal, adalah: (1) desainnya berangkat dari tema budaya lokal dan dikembangkan berdasarkan pengalaman awal budaya siswa. Komponen desainnya terdiri atas tema budaya lokal, tujuan integratif, materi pembelajaran terintegrasi dengan budaya lokal yang relevan, kegiatan pembelajaran terpadu berbasis budaya, alat-media dan sumber yang beragam dan kontekstual, serta komponen penilaian yang menekankan penilaian proses dan hasil; (2) implementasinya terdiri atas tiga tahap, yakni pengkondisian, penciptaan makna dan konsolidasi; dan (3) penilaian meliputi penilaian proses dan hasil.

Kedua, MPTBB terbukti secara signifikan lebih efektif meningkatkan apresiasi siswa terhadap budaya lokal simultan dengan penguasaan materi pelajaran bila dibandingkan dengan model pembelajaran yang selama ini digunakan guru.
Kesimpulan di atas memiliki sejumlah implikasi, yaitu (1) perubahan peran guru dalam proses pembelajaran dari pemateri ke pamandu; (2) guru membutuhkan pembekalan awal; (3) pemanfaatan secara optimal alat, media dan sumber yang tersedia di sekolah; (4) administrator dan komite sekolah membutuhkan orientasi agar memahami dan selalu aktif menyediakan sumber dan dukungan secara kontinu terhadap proses pembelajaran terpadu berbasis budaya yang dilakukan guru; dan (5) komunikasi dan sosialisasi kepada orang tua siswa maupun masyarakat. Temuan penelitian menghasilkan dalil-dalil sebagai berikut : (1) apresiasi siswa terhadap budaya lokal meningkat jika pembelajaran fokus pada tema yang dikembangkan berdasarkan pengalaman awal budaya siswa; dan (2) hasil belajar meningkat jika pembelajaran mengintegrasikan budaya.

\section{UCAPAN TERIMA KASIH}

Artikel ilmiah ini ditulis berdasarkan hasil penelitian dengan judul "Pengembangan Model Pembelajaran Terpadu Berbasis Budaya untuk Meningkatkan Apresiasi Siswa terhadap Budaya Lokal (Studi pada Mata Pelajaran IPS Sekolah Dasar)". Banyak pihak yang telah membantu penelitian ini. Oleh karena itu, sepatutnyalah kalau pada kesempatan ini penulis mengucapkan terima kasih dan penghargaan yang tinggi kepada semua pihak tersebut, terutama Prof. Dr. H. As'ari Djohar, M.Pd., Prof. Dr. Hj. Hansiswany Kamarga, M.Pd. dan Prof. Dr. Hj. Mulyani Sumantri, M.Sc. dari Universitas Pendidikan Indonesia serta Prof. 
Dr. Johanes Sapri, M.Pd. dan Prof. Drs. Safnil, MA, Ph.D. dari Universitas Bengkulu yang telah banyak memberikan kontribusi baik konsepsional maupun teknis sehingga penelitian ini dapat diselesaikan dengan baik. Ucapan terima kasih juga penulis tujukan kepada Direktorat Jenderal Pendidikan Tinggi Kementerian Pendidikan Nasional yang telah membantu penelitian ini melalui program Dana Bantuan Disertasi Doktor.

Terakhir penulis juga mengucapkan terima kasih kepada Pengelola Jurnal Cakrawala Pendidikan dari LPM Universitas Negeri Yogyakarta yang telah berkenan mempublikasikan artikel ilmiah ini.

\section{DAFTAR PUSTAKA}

Atmazaki. 1992. "Kemampuan Berpikir Kreatif dan Kualitas Interaksi dengan Karya Sastra sebagai Determinan Kemampuan Mengapresiasi Karya Sastra. Tesis, S2 Prodi Pengajaran Bahasa Indonesia PPs IKIP Bandung, Bandung.

Barr, R. D., Barth, J. L., and Shermis, S. S. 1978. The Nature of the Social Studies. Palm Spring: An ETS Publication.

Borg, W. R. and Gall, M. D. 1989. Educational Research: An Introduction. New York: Longman.

Dunkin, M.J. and Bidlle, B.J. 1974. The Study of Teaching. New York Holt: Rinehart and Winston.
Fink, L. Dee. 2003, Creating Significant Learning Eksperinces (An Integrated ApproachtoDesigning College Courses). San Francisco: Jossey-Bass.

Fogarty, R. 1991. How to Integrate the Curricula. Palatine, Illinois: IRI/ Skylight Publishing, Inc.

Hadi, N. 1997. "Pemanfaatan Sumber Belajar oleh Guru dan Pengaruhnya terhadap Hasil Belajar dalam Pengajaran Pendidikan IPS (Studi Kasus di Kelas III SDN Kauman I dan SDN Kauman II Kotamadia Malang-Jawa Timur. Tesis S2 PS PIPS SPs UPI, Bandung.

Norman, S. 1997. "Upaya Orang Tua dalam Membina Nilai-nilai Tabot di Lingkungan Keluarga. Tesis S2 PU IKIP Bandung, Bandung.

Pargito. 2000. Pembelajaran IPS dengan Model Pengalaman Belajar di SD Daerah Pedesaan Tertinggal (IDT)". Tesis S2 PS PIPS UPI, Bandung.

Rusyana, Y. 1984. Bahasa dan Sastra dalam Gamitan Pendidikan. Bandung: Diponegoro.

Samion, A.R. 2002. "Pengembangan Kreativitas Mengajar Guru dalam Pembelajaran IPS di Sekolah Dasar". Disertasi S3 PS PIPS SPs UPI, Bandung.

Sapri, J. 2000. Model Pengembangan Kurikulum Muatan Lokal Kewirausahaan dalam Mensukseskan Wajar 9 
Tahun di SMPN Wilayah Pantai Propinsi Bengkulu, Lembaga Penelitian UNIB, Bengkulu.

Sasongko, R. N. 2004. Penerapan Model Pembelajaran Interaktif Akademis Emosional Berbasis Kompetensi untuk Peningkatan Mutu Proses dan Hasil Belajar. Lembaga Penelitian UNIB, Bengkulu.

Sayakti, L. 2003. "Implementasi Konsep Lingkungan Hidup sebagai Sumber Belajar dalam Pembelajaran IPS di Sekolah Dasar". Tesis S2 PS PIPS SPs UPI, Bandung.

Schuncke, G. M. 1988. Elementary Social Studies: Knowing, Doing, Caring. New York: Macmillan Publishing Co Ltd.

Sudjana, Nana dan Ibrahim. 1989. Penelitian dan Penilaian Pendidikan. Bandung: Sinar Baru.

Sukmadinata, N. 2005. Pengembangan Kurikulum: Teori dan Praktek Bandung: Remaja Rosdakarya.
2006. Pengendalian Mutu Pendidikan Sekolah Menengah. Bandung: Refika Aditama. . 2007. Metodologi Penelitian Pendidikan. Bandung Remaja Rosdakarya.

Suprayekti. 2004. Pembaharuan Pembelajaran di SD. Jakarta: Pusat Penerbitan UT.

Suryatin, H. E. 1997. "Efektivitas Model Mengajar Resepsi dan Pendekatan Resepsi Sastra dalam Pengajaran Sastra untuk meningkatkan Kemampuan Apresiasi Sastra". Disertasi PS Bahasa Indonesia Pasca Sarjana IKIP Bandung, Bandung.

Tilaar, H. A. R. 2006. Standarisasi Pendidikan Nasional: Tinjauan Kritis. Jakarta: Rineka Cipta.

Wangsih. 2002. "Penggunaan Model Belajar Konkret-Semikonkret-Abstrak (KSA) dalam Pembelajaran Apresiasi Cerpen di SMU”. Tesis SPs UPI, Bandung. 